\title{
Nutrient diffusive fluxes from sediments in the northern Gulf of Aqaba, Red Sea*
}

\author{
SABER AL-ROUSAN, MOHAMMED RASHEED and MOHAMMAD BADRAN \\ Marine Science Station, University of Jordan and Yarmouk University, P.O. Box 195, Aqaba 77110, Jordan. \\ E-mail: s.rousan@ju.edu.jo
}

SUMMARY: Measurements of dissolved inorganic nutrients $\left(\mathrm{NH}_{4}^{+}, \mathrm{NO}_{2}^{-}+\mathrm{NO}_{3}^{-}, \mathrm{HPO}_{4}^{-2}\right.$ and $\left.\mathrm{SiO}_{2}\right)$ in pore waters $(\mathrm{PW})$ and overlying bottom waters (OBW) were carried out in sediments of two reefs on the Jordanian coast of the Gulf of Aqaba at different water depths down to $30 \mathrm{~m}$. One of the two sites was a marine reserve in front of the Marine Science Station (MSS) and the other hosted an Industrial Complex Zone (ICZ). The PW samples were retrieved using specially designed interstitial water traps. The concentrations in the OBW were within the typical range reported for oligotrophic tropical oceans. They showed minor variations with depth due to a well-mixed water column. Higher nutrient values were found at the ICZ compared to MSS suggested anthropogenic nutrient inputs. Our results showed significantly higher nutrient concentrations in the PW than in the OBW. The average concentrations in PW were about 16, 6, 9 and 5 times higher than the average values reported in the OBW for $\mathrm{NH}_{4}^{+}, \mathrm{NO}_{2}{ }^{-}+\mathrm{NO}_{3}{ }^{-}, \mathrm{HPO}_{4}^{-2}$ and $\mathrm{SiO}_{2}$ respectively. Average fluxes of the dissolved inorganic nutrients were estimated in this study using the pore water gradient concentration across the sediment-water interface. Average diffusion fluxes were in the ranges 1.41-46.44, 2.68-18.25, 0.04-0.60 and 9.68-16.85 $\mathrm{mol} \mathrm{m}^{-2} \mathrm{~d}^{-1}$ for $\mathrm{NH}_{4}^{+}, \mathrm{NO}_{2}{ }^{-}+\mathrm{NO}_{3}$ , $\mathrm{HPO}_{4}^{-2}$ and $\mathrm{SiO}_{2}$ respectively. Flux of all nutrients was higher at the MSS. This can be attributed to higher sediment organic matter content and high biological activity. The results of this study demonstrate (i) the importance of coral reef sediments in recycling nutrients for coral reef communities and (ii) the effect of pumping cooling water on the nutrient regeneration process.

Key words: nutrient fluxes, pore water, sediment-water interface, Gulf of Aqaba, Red Sea.

RESUMEN: DifusividAd DEl Flujo de nutRIENTES DESDE SEDIMENTOS EN El NORTE DEL Golfo DE AqABA, Mar Rojo. - En la costa de Jordania, en el Golfo de Aqaba, a diferentes profundidades por debajo de $30 \mathrm{~m}$ se han llevado a cabo determinaciones de nutrientes inorgánicos disueltos $\left(\mathrm{NH}_{4}^{+}, \mathrm{NO}_{2}{ }^{+}+\mathrm{NO}_{3}^{-}, \mathrm{HPO}_{4}^{-2}\right.$ y $\left.\mathrm{SiO}_{2}\right)$ del agua intersticial (PW) de sedimentos de dos arrecifes y de las capas del agua profundas (OBW). Uno de los dos lugares era una reserva marina en frente de la Marine Science Station (MSS) y el otro estaba enclavado en la zona de un complejo industrial (ICZ). Las muestras del PW se recogian utilizando unas trampas especiales diseñadas para aguas intersticiales. Las concentraciónes de nutrientes en la OBW estaban dentro del rango típico que se reporta para oceanos trópicales oligotróficos. Estas mostraban pequeñas variaciones con la profundidad debido a que la columna de agua estaba mezclada. Los valores mas elevados de nutrientes fueron hallados en la ICZ comparados con los de la MSS, lo que sugeria que los vertidos de nutrientes eran de origen antropogénico. Nuestros resultados mostraban concentraciones de nutrientes significativamente mas elevadas en las PW que en las OBW. Las concentraciones medias en la PW eran alrededor de 16, 6, 9 y 5 veces mas altas que el promedio de los valores alcanzados en las $\mathrm{OBW}$ para $\mathrm{NH}_{4}^{+}, \mathrm{NO}_{2}^{-}+\mathrm{NO}_{3}^{-}, \mathrm{HPO}_{4}^{-2}$ y $\mathrm{SiO}_{2}$ respectivamente. El promedio del flujo de los nutrientes inorgánicos disueltos fueron estimados en este estudio utilizando un gradiente creciente de la concentración del agua intersticial a través de la interfase agua-sedimento. El promendio del flujo de difusión oscilaba entre 1.41-46.44, 2.68-18.25, 0.04-0.60 y $9.68-16.85 \mu \mathrm{mol} \mathrm{m}{ }^{-2} \mathrm{~d}^{-1}$ para $\mathrm{NH}_{4}^{+}, \mathrm{NO}_{2}{ }^{-}+\mathrm{NO}_{3}-\mathrm{HPO}_{4}^{-2}$ y $\mathrm{SiO}_{2}$ respectivamente. El flujo de todos los nutrientes era mas alto en la MSS. Esto puede atribuirse a sedimentos con un mas alto contenido en materia orgánica y alta actividad biológica. Los resultados de este estudio muestran (i) la importancia de los sedimentos de los arrecifes de coral en el reciclaje de nutrientes por las comunidades del arrecife y (ii) el efecto de bombeo de aguas mas frias en los procesos de regeneración de nutrientes.

Palabras clave: flujo de nutrientes, agua intersticial, interfase agua-sediemto, Golfo de Aqaba, Mar Rojo.

*Received November 19, 2003. Accepted March 19, 2004. 


\section{INTRODUCTION}

Nutrients are minor constituents of the seawater that are of great importance for the growth of primary producers and small heterotrophs, such as bacteria (Bodungen, et al., 1985). Reef-building corals are distributed in oligotrophic tropical waters devoid of essential nutrients, yet they represent the most productive coastal marine ecosystem (D'Elia, 1988; Sorokin, 1993). This paradox is best explained by the rapid recycling of nutrients within the system (Richter et al., 2001; Rasheed et al., 2002). The recycling process, however, is not confined to the reef itself. There is a significant exchange of nutrient elements between the coral reef framework, the underlying sediments and the surrounding water (Capone et al., 1992). Nutrient exchange is controlled by physical and biological processes and is strongly dependent on the ambient nutrient concentration and distribution.

Sediments are well documented as providing an important source of essential inorganic nutrient such as nitrogen, phosphorus and silicon in the coral reef ecosystem (e.g. Boynton and Kemp, 1985; Capone et al., 1992; Howarth et al., 1995; Rasheed et al., 2002). Some $25-50 \%$ of the organic compounds produced by phytoplankton communities sink out of the water column to the sediment (Wollast, 1991). The intensity of degradation and mineralisation of the deposited organic matter in the sediments determines the rates of nutrient release to the overlying water column (Berner, 1980; Klump and Martens, 1981). Nutrient regeneration in the sediment supplies back a significant portion of phytoplanktonic nutrient demand during some seasons of the year (Koop et al., 1990; Cowan and Boynton, 1996).

The Gulf of Aqaba is a semi-enclosed basin characterised by a high diversity of coral reef communities (Schuhmacher et al., 1995). The lack of regular fresh water inflow and the high evaporation rate cause the saline conditions and contribute significantly to the oligotrophic nature of the Gulf system (Reiss and Hottinger, 1984; Badran, 2001). Nutrient contents within the Gulf of Aqaba are very low, because most of the waters flowing from the Red Sea through the Strait of Tiran are initially nutrientdepleted Red Sea upper waters (Reiss and Hottinger, 1984; Badran, 2001).

Jordan's only sea outlet is $27 \mathrm{~km}$ on the northeastern coast of the Gulf of Aqaba. This relatively small national coastline hosts several types of bottom habitats, with coral reefs being the most domi- nant. This small coastal stretch also hosts all the country's maritime activities: tourism, ports, marine reserves and industry. The aim of the current work is to better understand and quantify the budget of nutrients released from sediment at two coral reef sites: a marine reserve and an industrial complex. To this end, inorganic nutrient concentrations in the sediment pore waters (PW) and the overlying bottom waters $(\mathrm{OBW})$ were determined and the diffusive fluxes were estimated.

\section{MATERIALS AND METHODS}

\section{Study sites and water sampling}

The study was conducted across two coral reefs along the Jordanian coast of the Gulf of Aqaba (Fig. 1) in front of the Marine Science Station (MSS) and the Industrial Complex Zone (ICZ). The reef transects run perpendicular to the coastline from the coastline to offshore water about $30 \mathrm{~m}$ deep. Pore water (PW) and overlying bottom water (OBW) samples were collected by scuba divers. Sampling was confined to early summer, immediately after the spring bloom. The sampling stations were occupied three times during May 2003. Along every reef transect, samples were collected at 5, 10, 20, and $30 \mathrm{~m}$. OBW samples were collected at the bottom near the sediment water interface using $1 \mathrm{~L}$ polyethylene bottles. The PW samples were collected using specially designed interstitial water traps (Hesselein, 1976; Al-Rousan, 1998) made of $10 \mathrm{~cm}$ plastic tubes, 1.5

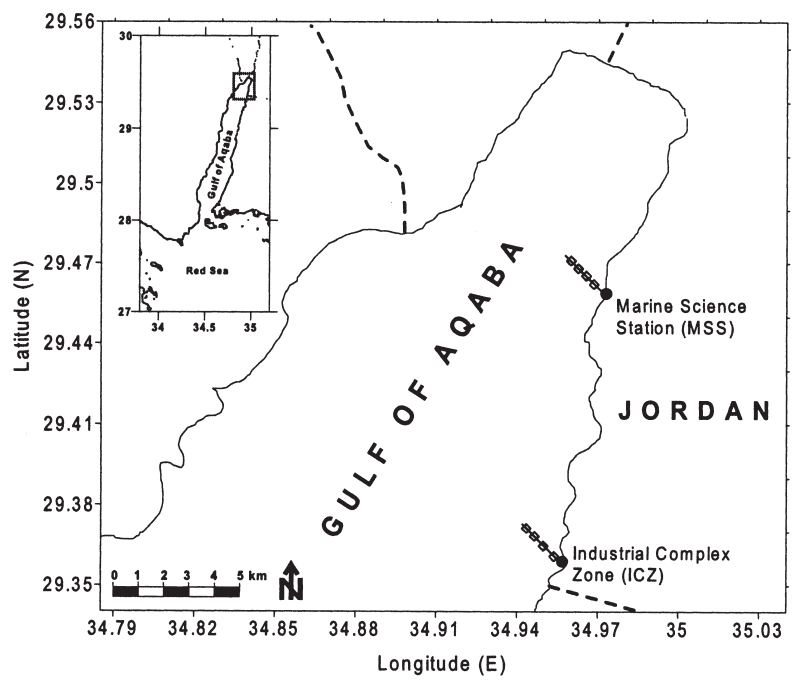

FIG. 1. - Site map of the northern Gulf of Aqaba. The quadrates along the two transects represent the sampling locations near the MSS and the ICZ at the Jordanian coast of the Gulf of Aqaba. 
$\mathrm{cm}$ in diameter. The two ends of the plastic tube were covered with net cloth (mesh size $45 \mu \mathrm{m}$ ). Outside the net cover, the tube was lipped with a $2 \mathrm{~cm}$ wide tube that allowed the trap to be covered with a rubber stopper during transport between the laboratory and the field. Pore water was collected by burying the traps about $2 \mathrm{~cm}$ in the sediment just below surface for one week.

Immediately after retrieval the sediment traps were carried to the laboratory in an ice box. In the laboratory samples were filtered using a pre-rinsed $0.45 \mu \mathrm{m}$ cellulose-membrane filter and analysed spectrophotometrically for ammonia, nitrite, nitrate, phosphate and silicate following the techniques established at the Marine Science Station, Aqaba, based on Strickland and Parsons (1972). All values were recorded as mean values of three replicates.

\section{Flux calculations}

Fluxes of ammonia, nitrite, nitrate, phosphate and silicate between sediments and the overlying water were calculated according to Fick's first law of diffusion as follows:

$$
\mathrm{F}=\mathrm{S} \times \mathrm{Ds} \times \mathrm{dc} / \mathrm{dz}
$$
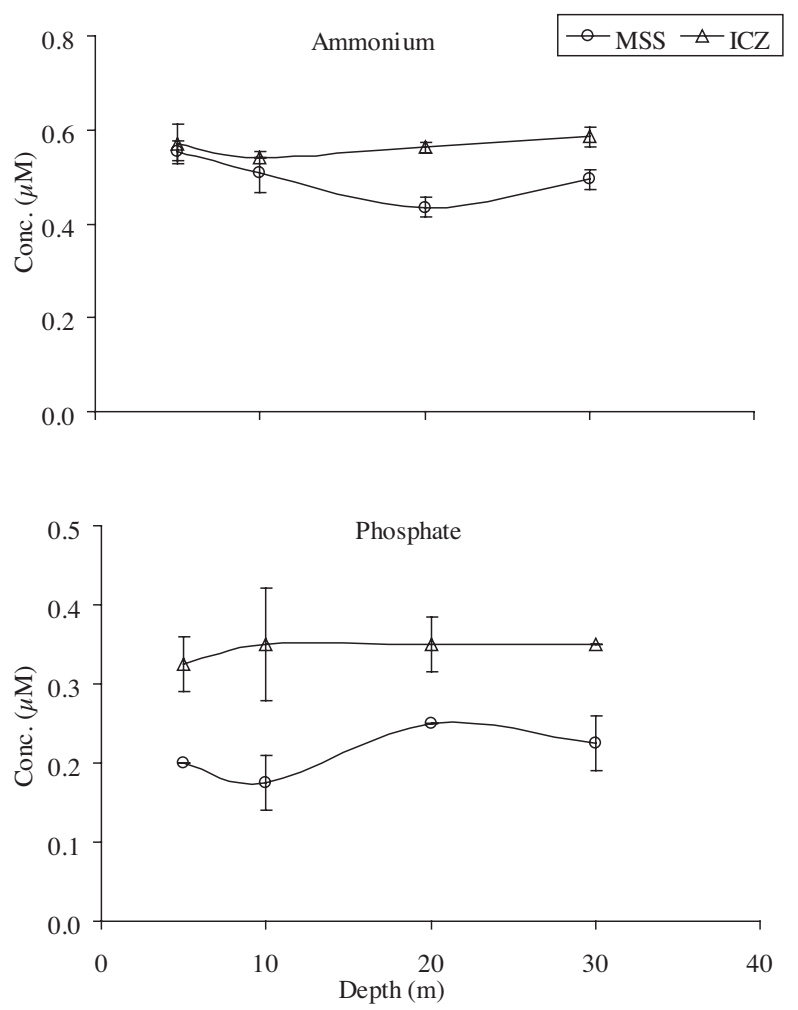

where $\mathrm{F}$ is the flux ( $\left.\mu \mathrm{mol} \mathrm{m} \mathrm{m}^{-2} \mathrm{~d}^{-1}\right), \mathrm{S}$ is the porosity of surface sediment (dimensionless), Ds is the diffusion coefficient $\left(\mathrm{m}^{2} \mathrm{~d}^{-1}\right)$, and $\mathrm{dc} / \mathrm{dz}$ is the concentration gradient in the overlying bottom waters $(\mu \mathrm{mol}$ $\left.\mathrm{m}^{-4}\right)$. The diffusion coefficients for ammonium, nitrate, nitrite and phosphate were taken from $\mathrm{Li}$ and Gregory (1974) for a water temperature of $25^{\circ} \mathrm{C}$, and corrected for a toruosity using a porosity of 0.47 and the toruosity-porosity relationship reported by Beekman (1990). The value for silicate was taken from Lerman (1979) and Callender and Hammond (1982) and corrected for toruosity. The calculated diffusion coefficients were equal to $8.85,6.66,6.70$, 2.97 and $5.89 \times 10^{-5} \mathrm{~m}^{2} \mathrm{~d}^{-1}$ for ammonium, nitrate, nitrite and phosphate and silicate respectively. Fluxes were calculated as mean values of the three replicate collections.

\section{RESULTS}

\section{Variation of nutrient concentrations in $\mathbf{P W}$ and OBW between different depths and sites}

Average nutrient concentrations $\left(\mathrm{NH}_{4}^{+}, \mathrm{NO}_{2}^{-}\right.$ $+\mathrm{NO}_{3}{ }^{-}, \mathrm{HPO}_{4}^{-2}, \mathrm{SiO}_{2}$ ) in the overlying bottom waters
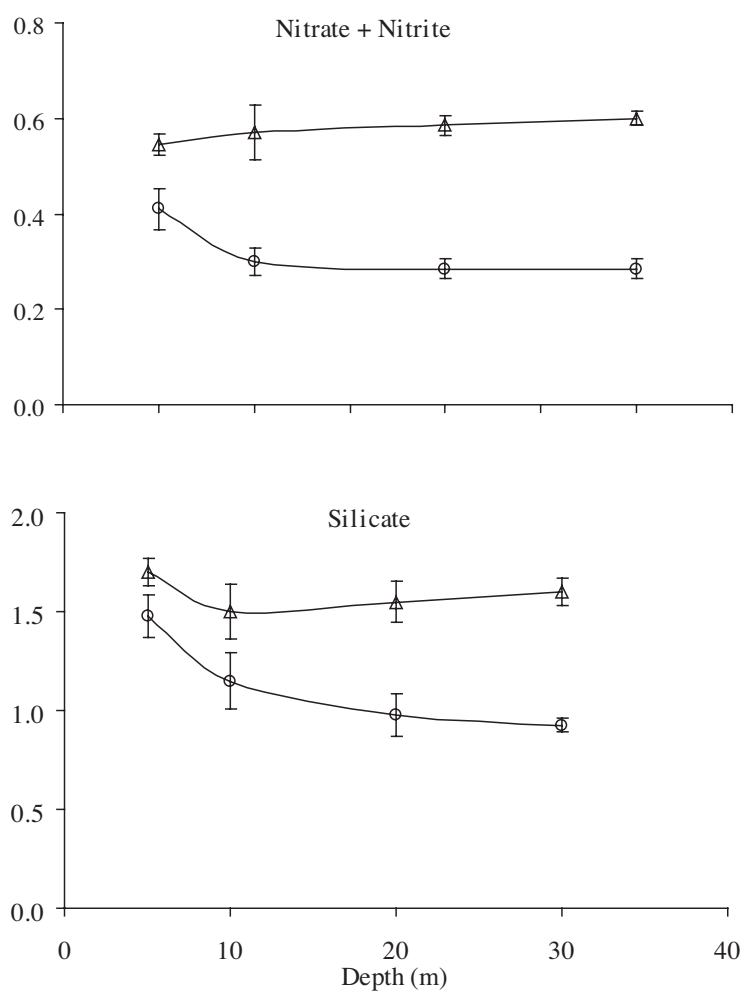

FIG. 2. - Average nutrient concentrations $(\mu \mathrm{M})$ in the overlying bottom waters (OBW) along different depths at both study sites (MSS and IZC) along the Jordanian coast of the Gulf of Aqaba. 

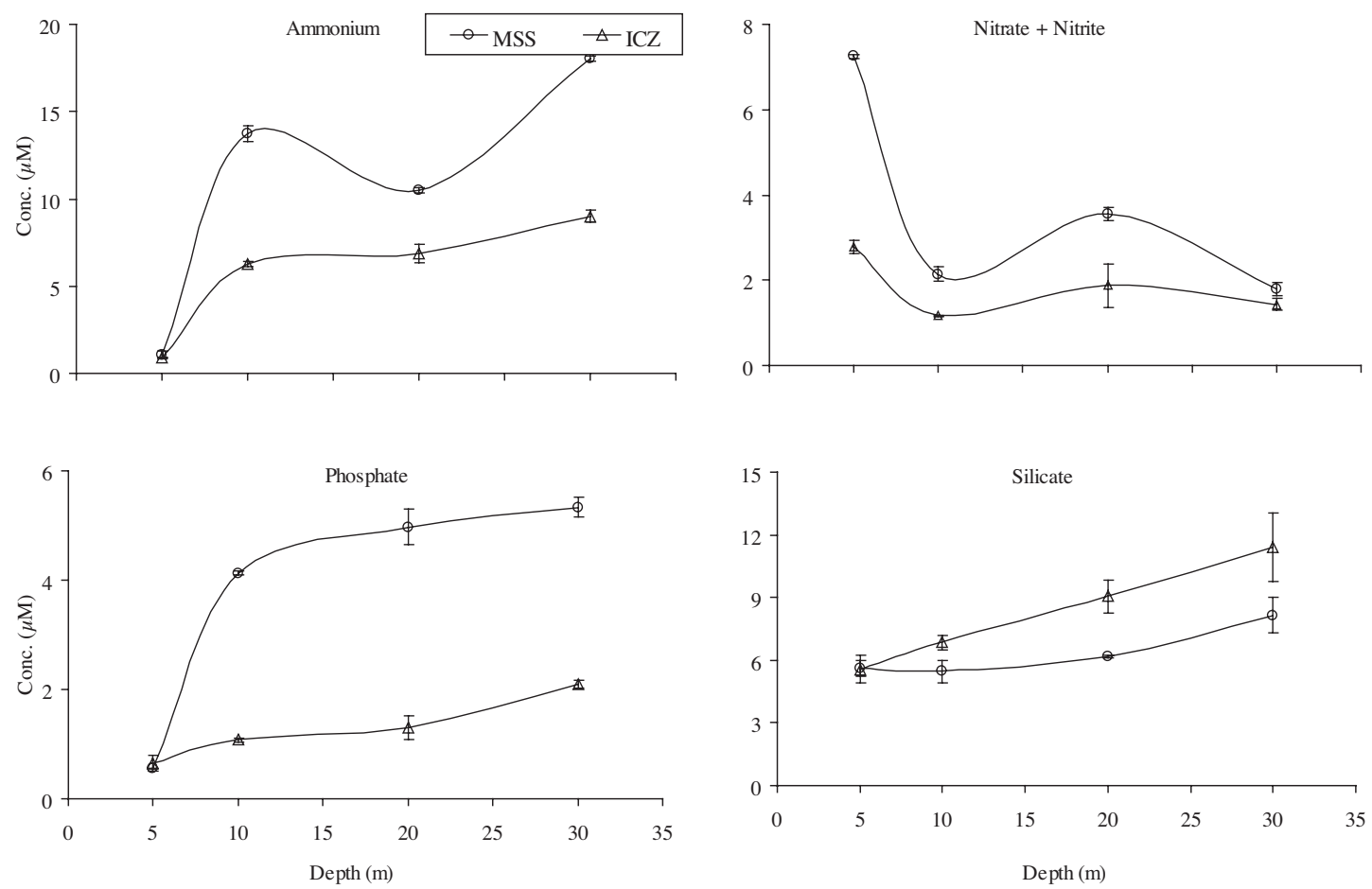

FIG. 3. - Average nutrient concentrations $(\mu \mathrm{M})$ in the pore waters (PW) along different depths at both study sites (MSS and IZC) along the Jordanian coast of the Gulf of Aqaba.

(OBW) at both study sites are shown in Figure 2. $\mathrm{NH}_{4}{ }^{+}$showed little change in the concentrations with depth at both sites. It ranged from 0.43 to 0.58 $\mu \mathrm{M}$ with an average of $0.53 \mu \mathrm{M}$ and was slightly higher at the Industrial site (ICZ) than at the reference site (MSS). Similar patterns were exhibited by all other nutrients, $\mathrm{NO}_{2}^{-}+\mathrm{NO}_{3}^{-}, \mathrm{HPO}_{4}^{-2}$ and $\mathrm{SiO}_{2}$. The values at the Reference and the Industrial sites were in the ranges 0.29-0.6, 0.175-0.35 and 0.93-1.7 $\mu \mathrm{M}$ and averaged $0.4,0.29$ and $1.39 \mu \mathrm{M}$ for $\mathrm{NO}_{2}{ }^{-}$ $+\mathrm{NO}_{3}^{-}, \mathrm{HPO}_{4}^{-2}$ and $\mathrm{SiO}_{2}$ respectively.

In contrast to nutrient concentrations in the $\mathrm{OBW}$, the concentrations in pore waters (PW) showed considerable variation between the different depths at the same site and between the two sites as well (Fig. 3). $\mathrm{NH}_{4}^{+}, \mathrm{HPO}_{4}^{-2}$ and $\mathrm{SiO}_{2}$ showed a general increase with depth. Concentrations of $\mathrm{NH}_{4}^{+}$ and $\mathrm{HPO}_{4}^{-2}$ at the MSS were higher than those at the ICZ, while silicate showed lower values at the MSS than at the ICZ (Fig. 3). For $\mathrm{NO}_{2}{ }^{-}+\mathrm{NO}_{3}$ concentrations tended to decrease with depth, but were also higher at the MSS than at the ICZ (Fig. 3).

\section{Nutrient flux}

The average nutrient flux ( $\mu \mathrm{mol} \mathrm{m} \mathrm{m}^{-2} \mathrm{~d}^{-1}$ ) estimated across both sites is shown in Figure 4. Following the concentration gradient the flux of all nutrients occurred in one direction from the sediment pore water to the overlying bottom water. Figure 4 also shows that the average flux of $\mathrm{NH}_{4}{ }^{+}, \mathrm{HPO}_{4}^{-2}$ and $\mathrm{SiO}_{2}$ tended to increase with increasing depth, while $\mathrm{NO}_{2}{ }^{-}+\mathrm{NO}_{3}$ showed an opposite pattern and decreased with depth. At the MSS, the average fluxes were in the ranges 1.11-36.53, 2.37-10.72, 0.243.56 and $5.74-10.0 \mu \mathrm{mol} \mathrm{m}^{-2} \mathrm{~d}^{-1}$ for different depths, while the values at the ICZ were in the ranges 0.62$17.53,0.93-3.50,0.23-1.22$ and 5.36-13.56 $\mu \mathrm{mol}$ $\mathrm{m}^{-2} \mathrm{~d}^{-1}$ for the different depths and the different nutrients $\mathrm{NH}_{4}^{+}, \mathrm{NO}_{2}^{-}+\mathrm{NO}_{3}^{-}, \mathrm{HPO}_{4}^{-2}$ and $\mathrm{SiO}_{2}$ respectively. In summary, the flux of inorganic nitrogen and phosphate was significantly higher at the MSS than at the ICZ (p-values were $<0.008$ and $<0.050$ at significance level of $5 \%$ for inorganic nitrogen and phosphate respectively).

\section{DISCUSSION}

\section{Variation of nutrient concentrations in PW and $\mathrm{OBW}$}

Inorganic nutrient concentrations in the overlying bottom waters (OBW) from this study were 

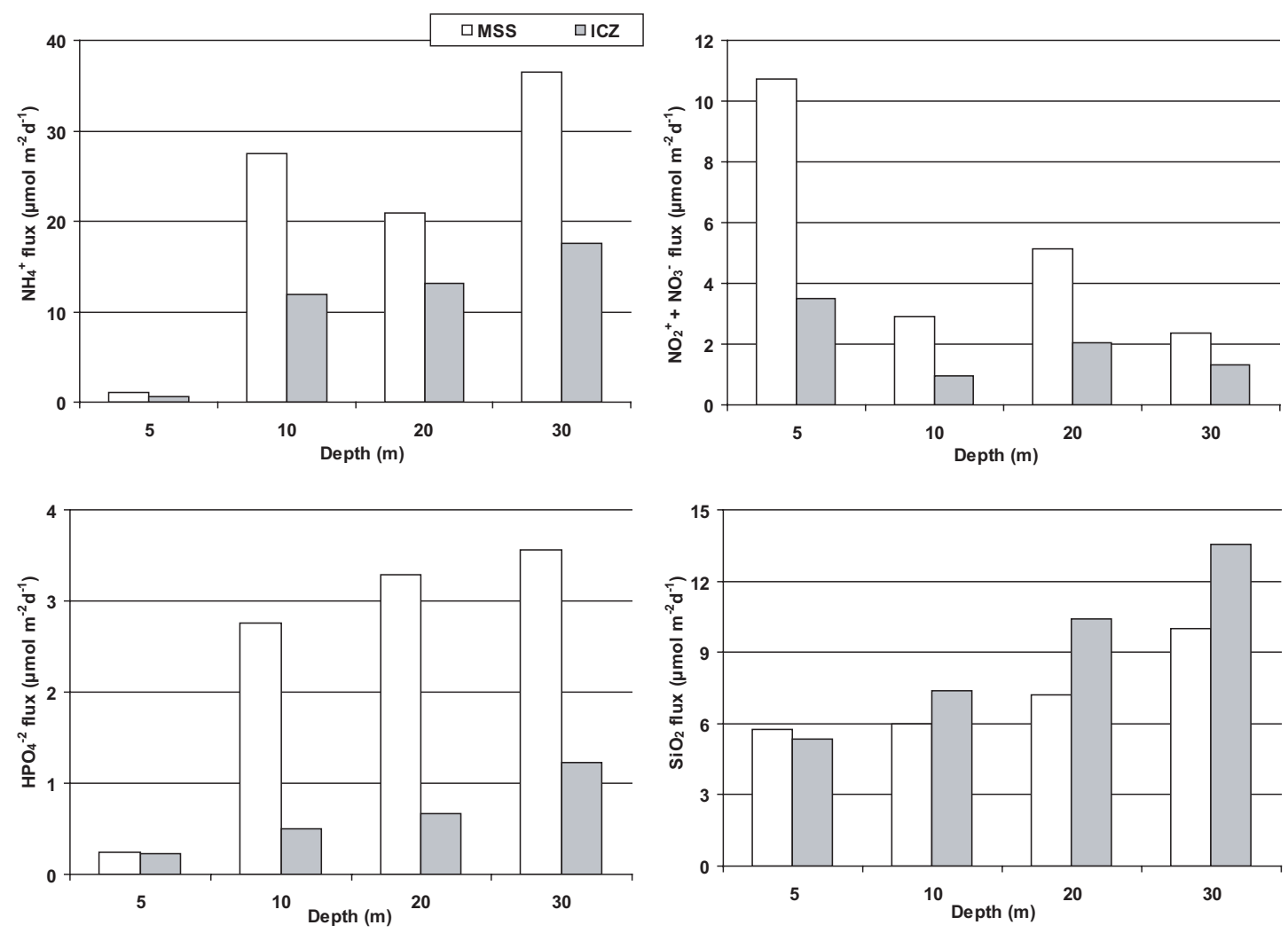

FIG . 4. - Average nutrient fluxes $\left(\mu \mathrm{mol} \mathrm{m}{ }^{-2} \mathrm{~d}^{-1}\right)$ from the sediments pore waters (PW) to the water column calculated for $\mathrm{NH}_{4}^{+}, \mathrm{NO}_{2}^{-}+\mathrm{NO}_{3}$, $\mathrm{HPO}_{4}^{-2}$ and $\mathrm{SiO}_{2}$ across the study sites (MSS and ICZ) along the Jordanian coast of the Gulf of Aqaba.

found to be within the typical range reported for oligotrophic tropical oceans (e.g. Tribble et al., 1990; Bell, 1991; Charpy-Roubaud et al., 1996; Rasheed et al., 2002) and for the water column and surface water during the season in the Gulf of Aqaba in particular (Badran and Foster, 1998; Badran, 2001). The lack of significant differences between depths (Fig. 2) might be attributed partially to the well-mixed water column during the collection period and to the sharp slope and close bottom surface distances between the stations (maximum distance $100 \mathrm{~m}$ ). In PW, the concentrations were much higher than in OBW. The average concentrations of $\mathrm{NH}_{4}^{+}, \mathrm{NO}_{2}^{-}+\mathrm{NO}_{3}^{-}, \mathrm{HPO}_{4}^{-2}$ and $\mathrm{SiO}_{2}$ for all stations were $16,6,9$ and 5 times the average values for the same parameters in OBW (Table 1). The continuous burial and decomposition of organic matter in the topmost layer of the sediment could be the main reason for these high concentrations in PW (Emerson et al., 1980; Balzer et al., 1985; Fuentes and Espino, 1990; Bertuzzi et al., 1996; Rasheed et al., 2003).

The general increase in ammonia and phosphate and the decrease in nitrite and nitrate in PW with depth (Fig. 3) is indicative of better oxygenation in the shallow PW than in deeper PW. It also indicates the possibility of detrital materials penetrating deep- er in the bottom sediment before undergoing complete decomposition near the water sediment interface. Due to the current reworking effect, shallow sediments usually have coarser sand than deep sediments. There is a general consensus that the coarser the sediment the better oxygenated it is, and the less likely to retain ammonia, because this ammonia oxidises rapidly to nitrate within the coarse well-oxygenated sediments (Capone et al., 1992). Further evidence is provided by the concentrations of nitrite and nitrate, which were inversely proportional to depth (Fig. 3), and by to the general decrease with depth of the oxygen concentration in PW. Oxygenation of the deeper sedimentary PW mainly results

TABLE 1. - Average nutrient concentrations $(\mu \mathrm{M})$ in pore waters (PW) and the overlying bottom waters (OBW) and ratios among all stations of the two transects along the Jordanian sector of the Gulf of Aqaba.

\begin{tabular}{lccc}
\hline Nutrient & $\begin{array}{c}\text { Average conc. } \\
\text { in OBW }(\mu \mathrm{M})\end{array}$ & $\begin{array}{c}\text { Average conc. } \\
\text { in PW }(\mu \mathrm{M})\end{array}$ & Ratio \\
\hline Ammonia & 0.53 & 8.30 & 16 \\
Nitrite & 0.08 & 1.10 & 14 \\
Nitrate & 0.37 & 1.65 & 5 \\
(Nitrite + Nitrate) & 0.45 & 2.75 & 6 \\
Phosphate & 0.28 & 2.51 & 9 \\
Silicate & 1.36 & 7.28 & 5 \\
\hline
\end{tabular}


from sediment mixing, as suggested by Sugai (1987). High silicate concentrations in PW were mainly attributed to the influx of atmospheric silicate-rich desert dust, as suggested by Al-Fukaha (1994), and the subsequent precipitation of the silicate on the sediment (Rasheed et al. 2002).

\section{Variation of nutrient concentrations between sites}

The higher nutrient concentrations in the OBW at the ICZ than at the MSS (Fig. 2) can be naively looked at as a result of anthropogenic inputs from the adjacent industrial and construction activities (e.g. fertiliser industry; thermal power station; gas pipe line). Although all industries do observe environmental measures and operate with satisfactory precautionary practices, under extreme conditions uncontrolled discharges of wastewater into the sea cannot always be avoided (Badran and Foster, 1998). However, a closer scrutinising look may lead to a different story. Although the cooling water from the industrial site comes back to the sea at temperatures very close to the ambient temperature, during the cooling process it goes through stage in which the temperatures exceed the ambient temperature by $10{ }^{\circ} \mathrm{C}$ or even more. Furthermore, the cooling water is quite often chlorinated. The high temperature and chlorination may very well affect both planktonic living organisms in the water and bacteria. Badran and Foster (1998) reported higher nutrient concentrations at the industrial site, but lower concentrations of chlorophyll $a$. Low viable phytoplankton biomass can be a good reason for high nutrient concentrations due to weak consumption. Also, decomposition of living material may be enhanced by the high temperature during the cooling cycle, which may be another reason for higher inorganic nutrient concentrations in the seawater at the industrial site. This very reason may also help to interpret the higher concentrations in PW at the MSS site than at the ICZ site. It could also be read by the higher organic matter content in the MSS sediments $(0.33 \%$ compared to $0.23 \%$, Al-Rousan, unpublished data), which is considered the main source for nutrient in PW, as suggested by Balzer et al. (1985). The same applies to the phosphorus concentrations in PW, which were similarly higher at the MSS than at the ICZ (about 3 times on average), which might be attributed to a high $\mathrm{CaCO}_{3}$ content in the MSS sediments (80\%, Rasheed et al., 2003). It has been long known that phosphate has a strong affinity for being adsorbed on reef carbonate sediments (Dekanel and Morse, 1978), and can also be trapped within the crystal lattice of carbonate granules (Rittenberg et al., 1955; Barrie et al., 1983; Balzer et al., 1985 and Sugai, 1987).

\section{Nutrient fluxes}

The decomposition of organic matter in sediments leads to a high nutrient concentration in PW; the gradients developing in the topmost sedimentary layer form the base for spontaneous diffusive fluxes to the upper water zone (Balzer et al., 1985). $\mathrm{NH}_{4}^{+}$, $\mathrm{NO}_{2}^{-}+\mathrm{NO}_{3}^{-}, \mathrm{HPO}_{4}^{-2}$ and $\mathrm{SiO}_{2}$ fluxes calculated from the measured PW gradient showed higher values at the MSS than at the ICZ (Fig. 4). Though the obvious direct reason was the higher nutrient concentrations in its $\mathrm{PW}$, resulting from high organic materials and biological activity (Al-Rousan, 1998; Rasheed et al., 2003), other reasons such as a stronger affinity of the nutrients at the ICZ to stay in the sediments cannot be overlooked. In a closer look at the diffusion of inorganic nitrogen species, $\mathrm{NO}_{2}^{-}+$ $\mathrm{NO}_{3}^{-}$flux appear marginal as compared to the flux-
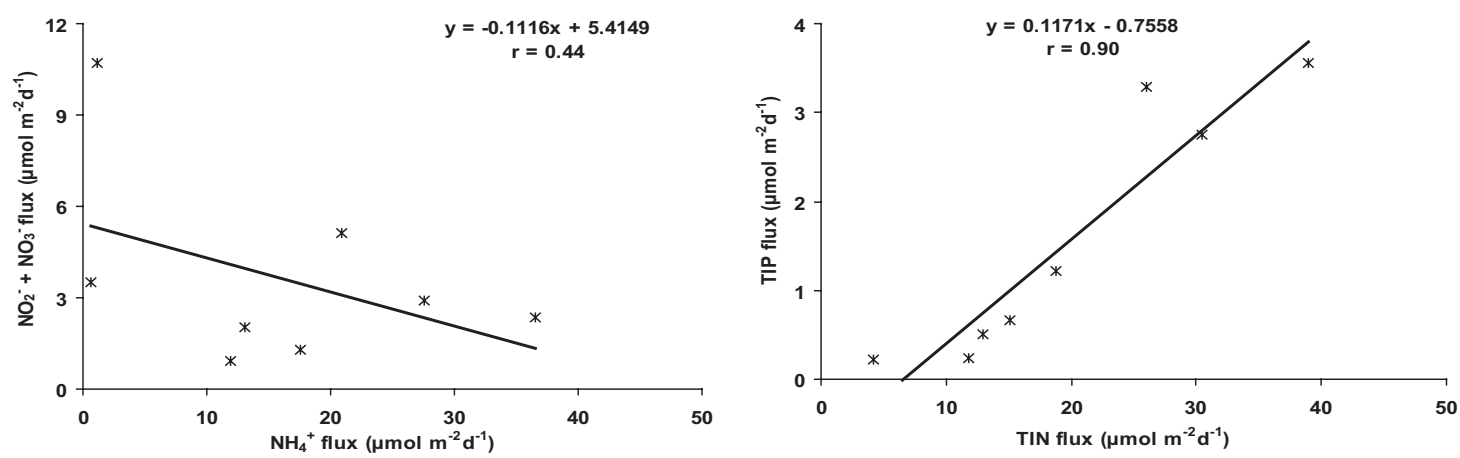

FIG . 5. - Regression between $\mathrm{NH}_{4}^{+}$and $\mathrm{NO}_{2}^{-}+\mathrm{NO}_{3}^{-}$fluxes $\left(\mu \mathrm{mol} \mathrm{m}{ }^{-2} \mathrm{~d}^{-1}\right)$, total inorganic nitrogen (TIN) and phosphate (TIP) fluxes $\left(\mu \mathrm{mol} \mathrm{m}{ }^{-2} \mathrm{~d}^{-1}\right)$ among all stations along the studied transects. 
es of $\mathrm{NH}_{4}{ }^{+}$(Fig. 5; $\mathrm{r}=0.44$ ). This is best understood as $\mathrm{NH}_{4}{ }^{+}$being the first inorganic product in the regeneration of nitrogenous organic material by microorganisms. $\mathrm{NO}_{2}{ }^{-}$and $\mathrm{NO}_{3}{ }^{-}$are formed in sediment only under well-oxygenated conditions by nitrifying bacteria through the nitrification process (Rittenberg et al., 1955; Billen, 1975). Ammonium fluxes from both sites and for all stations tended to increase with increasing inorganic phosphate fluxes (Fig. 5; r=0.93). This indicates that both inorganic phosphorus and nitrogen are tightly coupled because of their occurrence in a common phase and production from the same natural source, mainly by decomposition of living matter that has both elements in relatively fixed ratios, (Redfield Ratio). The increase in ammonium and phosphate fluxes from sediments with depth found herein (Fig. 4) is comparable to the results of Balzer et al. (1985) and Sundby et al. (1992), who found that the release rate of phosphate and total nitrogen from sediments shows a sharp increase under anoxic conditions, with ammonia being the major inorganic nitrogen species.

\section{CONCLUSIONS}

The present investigation showed that the inorganic nutrient concentrations in the bottom water column of the northern Gulf of Aqaba were within the typical range reported for oligotrophic tropical oceans. Continuous burial and decomposition of organic matter in the topmost layer of the sediment is the main reason for the high nutrient concentrations in the PW compared to those in the OBW. Average concentrations of $\mathrm{NH}_{4}^{+}, \mathrm{NO}_{2}^{-}+\mathrm{NO}_{3}^{-}$, $\mathrm{HPO}_{4}{ }^{-2}$ and $\mathrm{SiO}_{2}$ in $\mathrm{PW}$ among all stations in this study were $16,6,9$ and 5 times higher than the average values of the same species in the OBW. The variations in concentrations between sites can be mainly attributed to variations in supply and input of reactive organic matter.

The general increase in $\mathrm{NH}_{4}^{+}$and decrease in $\mathrm{NO}_{2}^{-}+\mathrm{NO}_{3}^{-}$concentrations with depth indicate that shallow PW is better oxygenated and/or capable of retaining more detrital materials than deeper PW. Carbonate sediments can accumulate more $\mathrm{HPO}_{4}{ }^{-2}$ as a result of strong adsorption of phosphorus on the surface of coral reef sediments. The low $\mathrm{NO}_{2}^{-}+$ $\mathrm{NO}_{3}{ }^{-}$fluxes associated with high fluxes of $\mathrm{NH}_{4}{ }^{+}$ result from $\mathrm{NH}_{4}{ }^{+}$being the first nitrogenous inorganic product in the decomposition process, fol- lowed by nitrite and nitrate, provided that the sediment oxygenation state allows.

Estimated inorganic nutrient fluxes show the importance of coral reef sediment in nutrient regeneration and emphasises the role of bottom sediments in supporting the coastal benthic community and the water column productivity in coral reef ecosystems flourishing in strongly oligotrophic waters.

\section{ACKNOWLEDGEMENTS}

We wish to thank all the technical and administrative staff of the MSS. Special thanks are due to Mr. A. Al-Momany for assistance with field work and to Mr. K. Trabeen and Ms. A. Tahan for assistance with the laboratory work. This study was funded by the Marine Science Station, Aqaba, Jordan.

\section{REFERENCES}

Al-Fukaha, F. - 1994. A textural and geochemical study on reefal sediments of the Gulf of Aqaba, and the input of airborne dust to the area, MSc thesis, Yarmouk University.

Al Rousan, S.A. - 1998. Sediment role in nutrient cycle within the coral reefs of the Gulf of Aqaba, Red Sea. Master thesis. Marine Science Station, Yarmouk University, Aqaba, Jordan

Badran, M.I. - 2001. Dissolved oxygen, Chlorophyll a and Nutrients: Seasonal Cycles in waters of the Gulf Aqaba, Red Sea. Aquat. Ecosyst. Health Manag., 4: 139-150.

Badran, M.I. and P. Foster. - 1998. Environmental quality of the Jordanian coastal waters of the Gulf of Aqaba, Red sea. Aquat. Ecosyst. Health Manag., 1: 75-89.

Balzer, W., B. Bodugen and F. Pollehne. - 1985. Benthic degradation of organic matter and regeneration of nutrients in shallow water sediments off Mactan, Philippines. Philippine Sci., 22: 30-41.

Bell, P.R.F. - 1991. Status of eutrophication in the Great Barrier Reef lagoon. Mar. Pollut. Bull., 23: 89-93.

Barrie, E., G. Kevin, G. Robin and J. Willington. - 1983. Occurrence of phosphorus and nitrogen in coral reef sediments on Davies reef in the central region of the Great Barrier Reef complex. Limnol. Oceanogr., 28 (3): 465-476.

Beekman, J.W. - 1990. Mathematical description of heterogeneous materials. Chem. Eng. Sci., 45: 2603-2610.

Berner, R.A. - 1980. Early Diagenesis: A Theoretical Approach: Princeton, NJ (Princeton Univ. Press).

Bertuzzi, A., J. Faganeli and A. Brambati. - 1996 Annual variation of benthic nutrient fluxes in shallow coastal waters (Gulf of Trieste, Northern Adriatic Sea). PSZN I: Mar. Ecol., 17: 261-278.

Billen, G. - 1975. Nitrification on the Scheldt Estuary (Belgium and Netherlands). Est. Coast. Mar. Sci., 3: 79-89.

Bodungen, B., W. Balzer., M. Boelter., G. Graf., G. Liebezeit and F. Pollehne. - 1985. Chemical and biological investigations of the pelagic system of Hilutangan Channel (Cebu, Philippines). Philippine Sci., 22: 4-24.

Boynton, W.R. and W.M. Kemp. - 1985. Nutrient regeneration and oxygen consumption by sediments along an estuarine salinity gradient. Mar. Ecol. Prog. Ser., 23: 45-55.

Capone, D., S. Dunham., S. Horrigan and L. Duguay. - 1992. Microbial nitrogen transformation in unconsolidated coral reef sediments. Mar. Ecol. Prog. Ser., 80: 75-88.

Callender, E. and D.E. Hammond. - 1982. Nutrient exchange across the sediment-water interface in the Potomac River esturary. Estuar. Coast. Shelf Sci. 15: 395-413.

Charpy-Roubaud, C., L. Charpy and G. Sarazin. - 1996. Diffusion- 
al nutrient fluxes at the sediment-water interface and organic matter mineralization in an atoll lagoon (Tikehau, Tuamotu Archipelago, French Polynesia). Mar. Ecol. Prog. Ser., 132: 181-190.

Cowan, J.L. and R.W. Boynton. - 1996. Sediment-water and nutrient exchanges along the longitudinal axis of Chesapeake Bay: Seasonal patterns, controlling factors and ecological significance. Estuaries, 19(3): 562-580.

D’Elia, C.F. - 1988. Concepts of ecosystem ecology: a comparative view. In: Pomeroy, L.R., Alberts J.J. (eds.) Ecological studies 67. Springer Verlag, New York.

Dekanel, J. and J.W. Morse. - 1978. The chemistry of orthophosphate uptake from sea water into calcite and aragonite. Geochim. Cosmochim. Acta, 42: 1335-1340.

Emerson, S., R. Jahnke., M. Bender., P. Forelich., G. Klinkhammer., C. Bowser and G. Setlock. - 1980. Early diagenisis in sediment from the eastern equatorial Pacific, I. Pore water nutrient and carbonate results. Earth Planet. Sci. Lett., 89: 57.

Fuentes, V.A. and G. de la Lanza-Espino. - 1990. Metabolism as determinant of nutrient exchange in organic-rich sediments of a coastal lagoon. Cienc. Mar., 16: 45-62.

Hesselein, R.H. - 1976. An in situ sampler for close internal pore water studies. Limnol. Oceanogr., 21: 912-924.

Howarth, R.W., H.S. Jensen., R. Marino and H. Postma. - 1995. Transport to and processing of phosphorus in near-shore and oceanic waters. In: Holm Tiessen (ed.), Phosphorus in the Global Environment. Transfers, Cycles and Management. pp. 323-346. SCOPE 54, John Wiley and Sons, Chichester.

Klump, J. and C. Martens. - 1981. Biogeochemical cycling in an organic rich coastal marine basin-II. the exploration of the Sea, Interlaboratory Report No. 3, pp. 10-22.

Koop, K., W.R. Boynton., F. Wulff and R. Carman. - 1990. Sediment-water oxygen and nutrient exchanges along a depth gradient in the Baltic Sea. Mar. Ecol. Prog. Ser., 63: 65-77.

Lerman, A. - 1979. Geochemical processes, water and sediment environment. John Wiley \& Sons, New York.

Li, Y.H. and S. Gregory. - 1974. Diffusion of ions in sea water and in deep-sea sediments. Geochim. Cosmochim. Acta., 38: 703714.
Rasheed, M., M.I. Badran, C. Richter and M. Huettel. - 2002 Effect of reef framework and bottom sediment on nutrient enrichment in a coral reef of the Gulf of Aqaba, Red Sea. Mar. Ecol. Prog. Ser., 239: 277-285.

Rasheed, M., M.I. Badran and M. Huettel. - 2003. Particulate matter filtration and seasonal nutrient dynamics in permeable carbonate and silicate sands of the Gulf of Aqaba, Red Sea. Coral Reefs, 22: 167-177.

Richter, C., M. Wunsch., M. Rasheed., I. Kötter and M. Badran. 2001. Endoscopic exploration of Red Sea coral reefs reveals dense populations of cavity-dwelling sponges. Nature, 413: 726-730.

Reiss, Z. and L. Hottngers. - 1984. The Gulf of Aqaba ecological micropaleontology. Springer Verlag, Berlin.

Rittenberg, S., K. Emery and L. Wilson. - 1955. Regeneration of nutrients in sediments of marine basins. Deep Sea Res. 3: $23-45$.

Schuhmacher, H., W. Kiene and W-Ch. Dullo. - 1995. Factors controlling Holocene reef growth: An interdisciplinary approach. Facies, 32: 145-188

Sorokin, Y.I. - 1993. Coral reef ecology. Springer-Verlag, New York.

Strickland, J. and T. Parsons. - 1972. A practical handbook of sea water analysis. Ottawa, Ontario: Fisheries Research Board of Canada Bulletin 167, 2nd ed.

Sugai, F.S. - 1987. Temporal changes in the sediment geochemistry of two southeast Alaskan fjords. Deep Sea Res., 34: 913-925.

Sundby, B., C. Gobeil., N. Silverberg and A. Muggi. - 1992. The phosphorus cycle in coastal marine sediments. Limno. Oceanogr., 37: 1129-1141.

Tribble, G.W., F.J. Sansone and S.V. Smith. - 1990. Stoichiometric modeling of carbon diagenesis within a coral reef framework. Geochim. Cosmochim. Acta, 54: 2439-2449.

Wollast, R. - 1991. The coastal organic carbon cycle: fluxes, sources and sink. In : R.F. Mantoura, J.M. Martin and R. Wollast (eds.), Ocean Margin Processes in Global Change, pp.365382.John Wiley and Sons, Chichester.

Scient. ed.: D. Vaqué 